Business Trends and Tendencies in Organization Design and Work Design Practice: I dentifying Cause-and-Effect Relationships 


\title{
Business Trends and Tendencies in Organization Design and Work Design Practice: I dentifying Cause-and-Effect Relationships
}

\author{
Tomislav Hernaus \\ thernaus@efzg.hr \\ Faculty of Economics and Business \\ University of Zagreb \\ Trg J. F. Kennedya 6 \\ 10000 Zagreb, Croatia
}

The views expressed in this working paper are those of the author(s) and not necessarily represent those of the Faculty of Economics and Business - Zagreb. The paper has not undergone formal review or approval. The paper is published to bring forth comments on research in progress before it appears in final form in an academic journal or elsewhere.

\section{Copyright February 2011 by Tomislav Hernaus}

All rights reserved.

Sections of text may be quoted provided that full credit is given to the source. 


\begin{abstract}
Current global business environment has a strong impact on theory and practice of organizations, as well as on working behavior of their employees. Increased complexity and competitiveness is changing settled ways of organizing and working. The ultimate search for the holy grail of achieving organizational effectiveness through better design solutions is gaining momentum. There are many possible areas and means for improvement. Great opportunities emerge from better understanding of contemporary organizational and work environment. To seize them, the link between organization design and work design tendencies will be emphasized. Through an in-depth theoretical research on current business trends and their impact on the changing nature of work in organizations, potentially very strong patterns between these two different environmental categories and levels of analysis will be identified. By analyzing widespread network of current trends and tendencies in organization design and work design field, useful insights will be provided for business practice, as well as for future scientific research challenges.
\end{abstract}

\title{
Key words
}

business trends, organization design, work design, systems approach

\section{JEL classification}

M10, L20, L21 


\section{Introduction}

Global business environment is characterized by exponentially changing requirements that are increasing complexity and raising the level of competitiveness. Settled ways of organizing and working have been put under question. In order to survive, organizations have to respond quickly to accelerating demands for increasingly specialized and integrated products or services, faster time-to-market capabilities, higher quality and more responsive services. Status quo is no longer an option, quite contrary, changeability becomes only possible and required organizational characteristic. Such strong need for adaptability and flexibility comes out from emerging business trends that are reshaping the map of business.

Various business aspects are changing significantly on a daily basis. The impact of those changes is stronger than ever, requiring new glasses for gaining better understanding of how to stay alive in corporate arena. Due to new business conditions reshuffling the cards, one needs to better understand various external and internal forces influencing organizations at various levels.

Many of emerging forces in business environment are not appropriately covered in the organizational literature and have not been put into the same context with their consequences manifested at organizational or work level. Although numerous authors have mentioned possible causes and consequences of required organizational changes (e.g., Galbraith, 2002; Goold \& Campbell, 2002; Mohrman, 2002; etc.), only few provided trivial cause-and-effect explanations of possible interactions at various levels.

In other words, it can be argued that so far differences and the relationship between business trends and organization design tendencies, together with changing nature of work and work design trends, has not been emphasized in a proper manner. There is a lack of visible connection and traceability between those very much intertwined aspects of business life. However, in order to gain better understanding of current requirements and to develop possible options for managers and consultants, there is a need for conducting a more thorough analysis.

By determining and making cause-and-effect relationships between uncertain and unpredictable business trends more visible on one side, and deterministic or eligible managerial decisions on the other, new insights useful for theory and successful practice of organizing might potentially be offered. Even more, the ground for achieving higher levels of organizational effectiveness might be set, while many possible areas and means for improvement might be recognized.

In order to create such a stimulating context for a development of both theory and practice, an in-depth theoretical research will be conducted. The research will be directed towards recognizing the link between various external forces, both present in general or specific environment, and their impact on making contemporary decisions regarding organization design and work design practices. Firstly, a detailed overview of current business trends, modern tendencies in organization design theory and practice will be presented. Secondly, changing nature of work will be addressed along with emerging work design practices. Thirdly, trends and contemporary design solutions at the organizational and work level will be separately explained, and systemic and multilevel effects between them will be recognized. Finally, the analysis of a widespread network of current trends and tendencies in the organization design and work design field will lead towards providing useful insights for current business practice, as well as for upcoming scientific research studies.

\section{Business Trends and Systems Perspective}

In order to recognize and to gain understanding of key design elements of organizations and their work, it is essential to recognize the key trends in business environment. Those trends are shaping not only the way of doing business, but are also determining the quality of life for each employee in particular and for people in general. The importance, multidimensional nature and complexity of mutual influences and existing relationships between various trends and tendencies call for applying the systems perspective. 
Firstly recognized in natural and biological environment (von Bertalanffy, 1951), the systems perspective has been ultimately applied and well accepted for thorough conceptualization of complex social systems' interactions (e.g., Katz \& Kahn, 1966; Thompson, 1967; Beer, 1980) where organizations have been understood as open systems with permeable boundaries (Swanson, 2007) and strongly dependent on their wider context. By addressing influence of specific and general environment, systems approach dominated the organizational science field in the mid-1960s (Shafritz \& Ott, 1987). It offered an intellectual basis for developing and understanding of various, dynamic interdependencies present in business environment.

There has been a continuing trend to employ systems theory and systems thinking as a broad conceptual platform for intervening in organizational settings (Lowman, 2002). Rummler and Brache (1995), as well as Swanson (2007) have proposed multilayered models of organizations as systems in which the influence of environment (economic, political, social, cultural, demographic, etc.) on organizational resources and its main characteristics (strategy, structure, technology, etc.) has been emphasized as one of the key determinants of organizational effectiveness. There are many other comprehensive conceptualizations and applications of systems thinking and systems approach regarding various aspects of conducting business, addressing its widespread usage and applicability.

As systems approach dominates much of the thinking both in a business and academic world, it will be applied for the analysis of intertwined relationships between various trends and tendencies emerging in everyday business practice. It is in compliance with the recognized pattern of reciprocal influences between behavior and work characteristics at the micro level, and organizational structure and design at the macro level. Additionally, the systems approach offers holistic appreciation at a more abstract level and thinking in relational terms, emphasizing that everything is connected to everything else and that it is often worthwhile to model businesses in terms of flows and feedback loops (Harmon, 2003).

Such an abstract reasoning is necessary for being able to anticipate future business challenges. It is only a starting point $-\mathrm{a}$ foundation - for designing and managing organizations that respond effectively to new reality of cutthroat competition and changing customer expectations (Rummler \& Brache, 1995). Although the future ultimately remains unknowable, its roots are in the present and the past. In other words, we can identify many of the key developments for the next few years, from what we observe today. Current trends in science and technology, economic development, government policies, social structure, demographics, and lifestyles will surely shape business environment for the remainder of the decade (Grant, 2009).

Although it is almost impossible to determine all possible factors directly influencing modern business practice, and indirectly various tendencies at organizational and work level, it is necessary to mention the few most important:

- Globalization;

- Competitiveness;

- Diversity;

- Flexibility and adaptability;

- Information technology;

- Outsourcing;

- Knowledge economy.

Globalization. Global movements along with political and technological changes, cultural and environmental shifts, and economic turnarounds have led to better availability and connectivity, as well as resulted in lower trade barriers (e.g., Ohmae, 1995). Such a context allowed doing business in various markets, establishing of numerous subsidiaries and developing offshore activities, as well as creation of globally competent workforce and global labor market (Parker \& Clegg, 2006). Due to lower transportation costs, globalization has made the world a global village, with new markets offering new challenges and opportunities (Hesselbein \& Goldsmith, 2009). Global interdependence has been broadened, deepened and accelerated in all aspects of work and life (Guillén, 2008), strongly influencing not only organizations, but national economies and individuals around the world as well. Nowadays, capability of doing business 
globally is seen not only as an option, but as a very important competitive advantage (Johansson et al., 1993).

Competitiveness. Competition is getting tougher and is reducing maneuver space on the market. The emphasis has been put on time-to-market capability, cost reduction and performance, as well as on customer orientation and creation of strong and sustainable partnership relations. Existing convergence of markets requires developing strategies for competing within a far broader market space. As new realities of the $21^{\text {st }}$ century have triggered new thinking about nature of strategy, the responsibilities of the corporation, and the role of management (Grant, 2009), if a company is to stay competitive, it must continually adapt its products and services meet the ever-changing evolving needs of the customer (Mozenter, 1999).

Diversity. The structure of workforce has changed during the years, where it has become more heterogeneous - including various aspects of gender, race, cultural background, religion, or personal traits. Present diversity is a source of innovation, although it can also create conflicts and numerous communication problems. It is necessary to show respect to cultural differences, as well as to different institutional frameworks. Furthermore, as knowledge, skills and competencies of particular groups of individuals have increased, the need for applying different approaches towards those different categories of employees should be emphasized.

Flexibility and adaptability. Organizational systems, processes and people can react differently in various situations. Although the importance of flexibility and adaptability, related to animal and plant species, has been thoroughly addressed by Darwin (1859) and his theory of natural selection, business people only recently realized processes of organizational Darwinism (mostly through population-ecology theory of organizations, e.g., Hannan \& Freeman, 1977; Aldrich, 1979; Carroll, 1984) where it became clear that sustainable development is possible only through being adaptive. More frequent changes emphasize the need for flexibility and adaptation, which can be achieved by using more organic structures, by implying autonomy and boosting innovation activities.

Information technology. Information technology (IT) has changed the nature of potential organizational solutions in a revolutionary way and has offered an alternative for traditional hierarchy loosening its rigidity and importance (Walton \& Nadler, 1994). It has enabled very cheap and quick distribution of information and data between numerous employees potentially geographically dispersed. By reducing interaction costs IT has not only removed traditional spatial and time constraints, but it has also eliminated the need for existence of several hierarchical levels. On the other side, introduction of IT powered by digital technologies and new communications media has encouraged better collaboration and teamwork, has improved the measurement and management of business processes (e.g., Burlton, 2001; Becker, Kugeler \& Rosemann, 2003; Harmon, 2003), as well as it has allowed development of knowledge management practices (e.g., Nonaka \& Takeuchi, 1995; Roos, 1996; Despres \& Chauvel, 2000). As technology evolves at a faster rate than ever, technological changes in general, and IT improvements in particular, should be seen as a force that is perceived to have the largest current and future impact on organizations.

Outsourcing. Due to increasing competition, organizations realized that it is impossible to be excellent in all areas of doing business. Consequently, a new business philosophy appeared, emphasizing the need for focusing on core business activities which create added value for customers, while at the same time, secondary activities, which are not optimized or not recognized as sources of competitive advantage, should be eliminated or outsourced to external partners (e.g., Duening \& Click, 2005). In other words, organizations should perform themselves only those activities at which they are the best, and try to develop their excellence in a particular area. For handling all other business issues they can engage partners, specialized for needed services. As a consequence, various organizations join together through contracts, joint ventures or business networks which offer mutual benefits for each party.

Knowledge economy. Although historically organizations were more production-oriented, where employees have been dealing mostly with simple and routine tasks, technological development and the rise 
of service sector have become triggers for further economic development, as well as a synonym for business success. Knowledge and knowledge economy have taken a dominant position over capital, natural resources or labor and represents the key source of competitiveness. Today, designing effective systems for creation, collection, acquisition, distribution and usage of knowledge has become the key challenge in organization design, while business analytics has been addressed as a new science of winning (e.g., Davenport \& Harris, 2007; Davenport, Harris \& Morison, 2010).

Aforementioned business trends are mutually interdependent and complementary in nature. By acting together, they put very demanding requirements on organizations and business society often providing hostile environmental and working conditions. With the aim of responding to changing and unstable context, academicians, managers and consultants are striving to develop new organizational solutions that will be able to respond and make organizations sustainable.

\section{Tendencies in Organization Design Theory and Practice}

In the first decade of the $21^{\text {st }}$ century the appearance of new tendencies in organization design has been stronger than ever. New organizational forms and managerial philosophies have been studied, introduced and proposed. Due to significant changes in the environment, traditional organizational boundaries have been changed significantly, requiring new ideas and approaches. Organizations realized that they need to not only focus on how well they are doing today, but also to be especially concerned with how well they can respond to changing environment (Lawler III \& Worley, 2006).

Possible response to emerging business trends is provided by specific tendencies developed in the organization design field. The most important are the following:

- Downsizing;

- Nature of organizational changes;

- Multidimensionality;

- Networking;

- Lateral integration;

- Customer orientation;

- Process orientation;

- Knowledge distribution.

Downsizing. Currently, there is a tendency directed towards de-layering organizations by removing managerial levels and giving more responsibility to teams and employees in managing and coordinating their work. Hierarchical levels are eliminated in order to enable making decisions faster and closer to the bottom-line. Information technology made possible a better communication and larger spans of control. Accordingly, flatter structures with less hierarchical levels have been developed, in which autonomy and responsibility are present at lower levels. By using downsizing strategy, costs are significantly reduced because fewer workers are employed per unit of output to some previous level of employment (Cameron, Freeman \& Mishra, 1993).

Nature of organizational changes. Constant change is a derivative of all other macro forces. As a result, organizations are changing more often, faster and more significantly than earlier. The process of "patching" - where new organizational units are continually being created, merged, and redefined to foster initiative is strongly present. Necessary knowledge and skills needed for designing whole-scale systems are changing. Managers and consultants should learn how to simultaneously analyze, design and implement organizational solution (Walton \& Nadler, 1994). Furthermore, due to environment and organizational tendencies getting more turbulent in future, and due to changes getting more frequent (Pasmore, 1994), a great challenge is to build "dynamically-stable" organizations which will be more flexible and adaptable, but at the same time will be able to keep their basic identity. 
Multidimensionality. As business environment is becoming more complex, more competitive, and less predictable, surviving requires performance at a higher level with a broader range of capabilities. Building multiple capabilities and achieving excellence across multiple areas requires transition from onedimensional focus (e.g., on functions or products) towards design solutions that allow simultaneous focus on two or more dimensions (e.g., functions, products, regions, customers, distribution channels, processes, etc.). By addressing several dimensions at the same time and by dealing with complexity internally, organizations can be more sensitive and more approachable from customers' viewpoint. Although in certain cases it is not possible to avoid multidimensionality, larger organizations should manage its complexity in an intelligent way.

Networking. Organizations are getting more connected to their stakeholders. Strategic alliances and partnerships are more common, the emphasis has been put on developing long-term relations with suppliers, partners and customers, while coordination and information sharing along the value chain has been recognized as an important practice. Intranets that link together internal units of the enterprise with outside suppliers, customers, and partners have had a major influence in blurring corporate boundaries (Grant, 2009). Furthermore, Internet technology plays a critical role in increasing efficiency of communication and coordination within networks, and allows virtual way of conducting business through formation of multi-firm collaborative networks (Miles, Miles \& Snow, 2006) and communities of practice (Snow \& Strauss, 2008).

Lateral integration. Numerous signs indicate the importance of lateral integration in modern organizations. The traditional organizational model, comprised of functional units integrated by top management, is more often getting replaced by organizational models with capability of integrating a larger number of business units with a common focus on customers, products, projects or processes (Galbraith, Lawler III et al., 1993). The new lateral orientation and lateral integrative mechanisms (e. g., Mintzberg, 1979; Galbraith, 1994; Mohrman, 2006) will upgrade and, to a certain extent, replace the traditional hierarchical logic.

Customer orientation. Customers are getting more demanding, and the emphasis is put on their satisfaction. They do not longer tolerate lower quality or bad service. Therefore, in order to keep present and attract new customers, organizations should be designed, led and managed in such a way that customers can easily approach them. That means the number of contacts from customer's viewpoint with an organization ("moments of truth") should be minimized. Besides, numerous organizations are trying to differentiate through ideas, knowledge, experience and capability of delivering a complete product and service adapted to their customers' needs (Galbraith, Downey \& Kates, 2002), which results in front-back organizational solutions.

Process orientation. The desire to improve coordination across multiple, linked capabilities and to reduce non-value-added activities has encouraged organizations to align their structures more closely with their internal business processes. By acknowledging and focusing on business processes, organizations gain more realistic view of functioning (Bosilj Vukšić, Hernaus \& Kovačič, 2008). Such horizontal approach allows significant savings in terms of time, resources and money, while providing higher quality and better customer and employee satisfaction. Traditional functional barriers disappear and organizations are becoming more integrated by implementing process-based organizational solutions (e.g., Ostroff, 1999; Gardner, 2004; Crosetto \& Macazaga, 2005; Hernaus, 2008).

Knowledge distribution. Capabilities, skills and knowledge of organizational members have been identified as the most valuable capital which cannot be copied, but needs to be developed. By introducing a learning organization concept (Senge, 1990), as well as developing knowledge management practice, a lot of attention is directed towards organizational learning, knowledge collection and distribution in an organization. Quality systems for data collection and analysis, as well as for their processing and distribution, are becoming a very important source of organizational capabilities and competitiveness. 
Presence of a strong development of various design activities and options is evident. Value in organizations is created through unique and internally various organizational forms. While new organizational solutions are constantly being developed, the older ones are being thought over and adapted, in order to create organizational capabilities providing competitive advantage (Lawler III, 1996). Front-back organization could be recognized as one of the most influential emerging organizational forms, together with network organization, ambidextrous organization, and process-based organization. These organizational shapes are characterized by multidimensional and organic structures primarily founded on teamwork. In other words, teams have become the main building block of an organization present in various structural solutions, either traditional or modern.

\section{Changing Nature of Work}

Today's work differs significantly from the traditional model or from the recent working practice. Employees are better informed, better educated, and less tolerant of work for the sake of work. Physical labor has been replaced by information and knowledge work, supervision by direct observation is often impossible, and service sector has supplanted manufacturing as the dominant employer. Furthermore, the rapid pace of change now demands that decisions must be made at the working level (Tenner \& DeToro, 2000).

Nature of work is changing dramatically. Previously, work tasks could be anticipated, they were mostly routine, structured, explicit and individual in nature. Currently, as well as in the future, work activities will be ambiguous, abstract, team-oriented, changeable and from time to time chaotic (Cohen \& Mankin, 1998). Many new forms of work have recently appeared, e.g. virtual work, distributed work, project work, flexible work, contingency work, telework, etc. Such new and challenging nature of work is already empirically confirmed (e. g., Kersley et al., 2006). It has been confirmed that economic, technological and social development has thoroughly changed work practice (Edwards, Scully \& Brtek, 2000). Information technology in particular stimulated the appearance of a new work environment (Howard, 1995) by making it more abstract and flexible.

The nature of work continues to change on a constant basis, while velocity of subsequent changes in work design practice is becoming higher each day. In order to be able to understand new work design trends, one should firstly recognize the most important changing aspects of the nature of work, which are changing rapidly and irretrievably: (1) sectoral changes; (2) changes in individual characteristics of employees; (3) changes in demographic characteristics of the workforce; and (4) cognitive changes and the emergence of knowledge work.

Sectoral changes in the nature of work imply a change from a production-oriented work (products are produced by using physical labor) towards a service-oriented work (services are delivered on the knowledge basis), as well as a direct contact with customers. Job focus is changing as well, mostly in the sense of a number of employees in different sectors and occupations, and moving from traditional bluecollar workers towards the white-collar and knowledge workers.

Individual characteristics of employees have significantly changed. Employees want to know the purpose of their jobs and want to have an insight in the whole business process. They want to know how they contribute to the organization, but they also want to perform a meaningful work. Above all, they want to have a control over and perform interesting work which will utilize their potential and talent. Such aspirations come out of a higher educational level, which demands more complex forms of work design itself, in spite of majority of individuals still being trapped at jobs that frustrate and constrain them.

Besides individual characteristics and preferences of employees, their present structure, i.e. demographic characteristics of workforce, is also changing in ways which significantly affect work design. Demographic issues influence theory and practice of work design in a few different ways. Firstly, a changing structure of workforce will cover additional, new work characteristics, besides those traditional, 
already explained. Secondly, a moderate impact of age, gender and race characteristics might result in different relationships between work characteristics and performance outcomes. Finally, factors such as age, gender and ethnical status have an impact also on antecedents and processes of work design (Parker \& Wall, 2001).

Finally, the cognitive changes in the nature of work and emergence of knowledge work are becoming more evident. As knowledge gets obsolete every 5 to 10 years, and cognitive capability of humankind is getting more sophisticated, hence realizing the importance of continuous, life-long learning and forming more complex, intellectually more demanding tasks. According to Cohen and Mankind (1998) a work, as a general category, is being based more on knowledge. Strategic competencies, strong interdependency, process orientation, geographical connection, generating and distribution of knowledge have a strong impact on work design, i.e. on its dynamism, cross-functional nature, systemic focus, and integration.

While the abovementioned changes in the nature of work are evident and have been widely identified, theories of work design have not been developed concomitantly. Theoretical argument has in a certain way stopped with the Hackman and Oldham's Job Characteristics Model developed during the 1970s, leaving a plenty of space for improvement. However, recent changes in the nature of work have renewed the research interest and launched a new stream in a work design area.

\section{Work Design Trends and Practice}

Work design theory has a strong base in business practice. Designing work is very complex and responsible activity that influences performance of business processes (Sikavica \& Novak, 1999). Therefore, it is important to identify state-of-the-art and future trends in work design used by numerous, primarily highperforming organizations. Those best practices very often set standards for majority of other organizations which lag behind, passively observing and implementing new solutions with a larger time lag after its occurrence.

Even for the most successful organizations it can be said that technological forces primarily, as well as other environmental forces, dictate change in premises of work design and mechanisms for motivating employees (Mohrman, 2003). That results in numerous new conceptualizations and suggestions, out of which, as the most significant trends, one can extract the following: (1) systemic character and higher complexity of work; (2) lack of clear job boundaries; (3) variability of work design; (4) stronger focus on work and competencies (rather than jobs); (5) higher work interdependence; (6) emergence of group-based forms of work design; (7) wider use of various knowledge, skills and competencies; (8) optimal utilization of human potential; and (9) job crafting.

Systemic character and higher complexity of work. Instead of traditionally focusing on boxes in organization chart, lines of responsibility and individual tasks, today, work design is getting more focused on connecting employees and tasks in the system as a whole. Such an integration of tasks into complete processes does not present an option but the only way for performing work and achieving results (Burlton, 2001). This is also supported by the fact that work of an individual is becoming more cross-functional and multi-level in nature. Correspondingly, organizational contribution and system aspects of knowledge work have been getting more complex (Swanson, 2007), and the increasing complexity of work is becoming an ascending problem (Bryan \& Joyce, 2007).

Lack of clear job boundaries. Technology, dynamic global markets and flattening of organizational structures have caused jobs being no longer static as they used to be. Limits of responsibility between work in many environments are getting more unclear, and employees are encouraged to perform work at anytime and anywhere (Cohen \& Mankin, 1998). Therefore, it is not surprising that work analysis can be applied on a broad range of jobs and roles focusing on general business activities and broad dimensions (Sanchez \& Levine, 2001). Hence the term work getting more common instead of traditionally accepted term job. 
Variability of work design. Forms of work design should not be permanent and should not be presented in such a way. Exactly the opposite, work design should represent strategic and operative tools which change as a consequence of a change in strategy or combination of activities which it comprises of (Mohrman, 2003). That means organizations and related jobs have become more fluid than tasks themselves (Swanson, 2007). By using dynamic work assignments and relationships, individuals are temporarily given responsibility for performing a group of tasks. Furthermore, their skills and needs of the organization, as well as a combination of tasks for which they are responsible, are being adjusted (Lawler III \& Worley, 2006).

Stronger focus on work and competencies. Modern trends in doing business made conventional workplace in numerous firms obsolete. Knowledge economy has changed organizational and technological environment in which employees are being flexibly allocated to a larger number of tasks and roles which require their competencies (Mohrman, 2003) or to a changing combinations of tasks that need to be performed (Finegold, Lawler III \& Ledford Jr., 1998). Such a practice is popularly called de-jobbing of the organization and has led some experts to announce the end of work places as fixed, stable collective of predefined tasks and responsibilities (Bridges, 1994). Therefore, organizations are starting to radically abandon the traditional concept of job and at the same time implement the concept of work.

Higher work interdependence. Work is getting multifunctional, oriented towards consumers and business processes. Products and services are getting more complex, requiring more knowledge, skills and competencies from employees, and often offering customers integrative programmed solutions. Such a way of carrying out business activities requires a high level of interdependency between members in order to perform work (Galbraith, Downey \& Kates, 2002). What is also imminent is a need for a higher lateral coordination, under which individuals should make trade-off decisions more often but also cooperate better between themselves.

Emergence of group-based forms of work design. Work is more often performed in groups rather than individually. Organizations assign working tasks to multifunctional teams in order to integrate different parts of organization. A trend towards teamwork is strongly emphasized in the literature (e.g., Mohrman, Cohen \& Mohrman Jr., 1995; Kersley et al., 2006; etc.), and one can anticipate that group-based forms of work design will be even more common in the future. Such practices will lead to a higher work complexity, and consequently to a necessary adjustment of present organizational concepts, strategies, methods, and skills.

Wider use of various knowledge, skills and competencies. Employees that possess various knowledge, skills and competencies for performing different tasks are getting sought for more often. People are required to undertake both exploratory and exploitation activities as part of their jobs. Therefore, numerous organizations are rotating from traditional idea of one person performing specialized work and putting emphasis on a development of human resources which simultaneously understand broader strategic issues and specific tasks in organizational environment (Nadler et al., 1992). Although specialists will still be necessary in organizations, they will have to expand their knowledge, skills and competencies in order to respond on new organizational requirements. They will be expected to learn fast and to demonstrate deep understanding of system aspects of working tasks.

Optimal utilization of human potential. The usage of competencies and systems of human resources management based on competencies and skills is getting more common and offers a possibility for adjustment of work situations to available combination of individuals. Instead of efforts directed to alignment of individuals with present job descriptions, it is getting possible to adjust work roles, project goals and team structures to a talent available (Lawler III \& Finegold, 2000). What is getting extremely important is to utilize the full potential of each employee, what will lead to a higher level of job satisfaction, higher work performance, minimal absence rate, and consequently indirectly to a higher organizational success (Lawler III, 1996). Therefore, work should be designed in a way to increase, i.e. motivate, potential development of each employee. 
Job crafting. Wrzesniewski and Dutton (2001) recognized a creative and improvisation process which displays how individuals adapt their jobs locally in ways that create and support sustainable definitions of their job, as well as their role in it. It is about physical and cognitive changes implemented by individuals in tasks or relational frontiers of their jobs. These individuals actively form their job by physically changing frontiers of tasks, changing relational frontiers and/or changing cognitive frontiers of a job. In that way, they create different jobs for themselves in a broader context of already defined jobs.

What is evident from the above defined trends, that is, changes of the nature of work and related forms of work design, context of job today is significantly different from the one in which main theories of work place design were developed (during the 1970s). That does not mean there is no relation and continuity, but only indicates a necessary reorientation and a need for paying more attention to causes of work design and a broader context which leads to changes mentioned.

\section{Interplay between Organization Design Tendencies and Work Design Trends}

Organization design and work design represent very broad and highly developed concepts that were historically studied separately. Although such practice has evolved from singular and somewhat separate developments of macro and micro perspectives in the area of organization science, their possible interactions and cause-and-effect relationships need to be studied more thoroughly. To make this possible, they should be positioned in and understood as parts of the same business and scientific context.

The existence of interaction and reciprocal relationships between macro and micro aspects of organizations has been recognized 30 years ago (e.g., Roberts, Hulin \& Rousseau, 1978; Van de Ven \& Ferry, 1980; Moorhead, 1981; Griffin, 1982; Mossholder \& Bedeian, 1983; Liska, 1990). However, only recently the particular focus gained the momentum due to strengthening of multilevel approach (e.g., Klein \& Kozlowski, 2000), which theoretically and methodologically makes integration of issues at various levels of analysis possible.

By combining and connecting macro and micro perspectives the multilevel approach throws a new light on a complex relationship between organization design and work design resulting with a more complete understanding of their numerous interactions. Namely, as it is identified that many problems, present at one level of analysis, manifest at others, it is also necessary to analyze the impact of organizational context on work design, and vice versa, how aspects of work design shape the practice of organizational design.

Using a multilevel approach and taking into consideration contextual causes enables a better anticipation of forms of work design present in different environments, as well as understanding the impact of comprehensive changes in business environment on work design. By including contextual and macroorganizational characteristics and their impact on micro-organizational features make design practices more clear and anticipated, while results of empirical research become more consistent. Such a bottom-up approach is far more ingrained and more dominant than the opposite impact of job design and microorganizational aspects on organization design and macro-organizational issues. Therefore, the focus in the paper has been put solely on the first mentioned and that is on the relationship between different categories, i.e. levels, of trends and tendencies present in modern business.

Current trends and tendencies in business environment should be somewhat distinguished regarding their level of analysis and level of influence. Business trends can be characterized as the broadest, highest-level category, because of their strong and widespread influence present at the industry, country and/or global level. In general, they strongly influence tendencies in organization design, while their impact on the nature of work is somewhat weaker, although exists. Furthermore, at the organizational level, tendencies and modern organization design ideas strongly shape and prescribe useful work design practice. The practice is also under a strong influence of the changing nature of work where the latter is indirectly caused by emerging business trends. It is obvious that relationships between different categories and trend levels are 
quite complex, with numerous direct and indirect links existing, as it is aggregately shown in the following figure.

Figure 1: Conceptual interactions between trends and tendencies

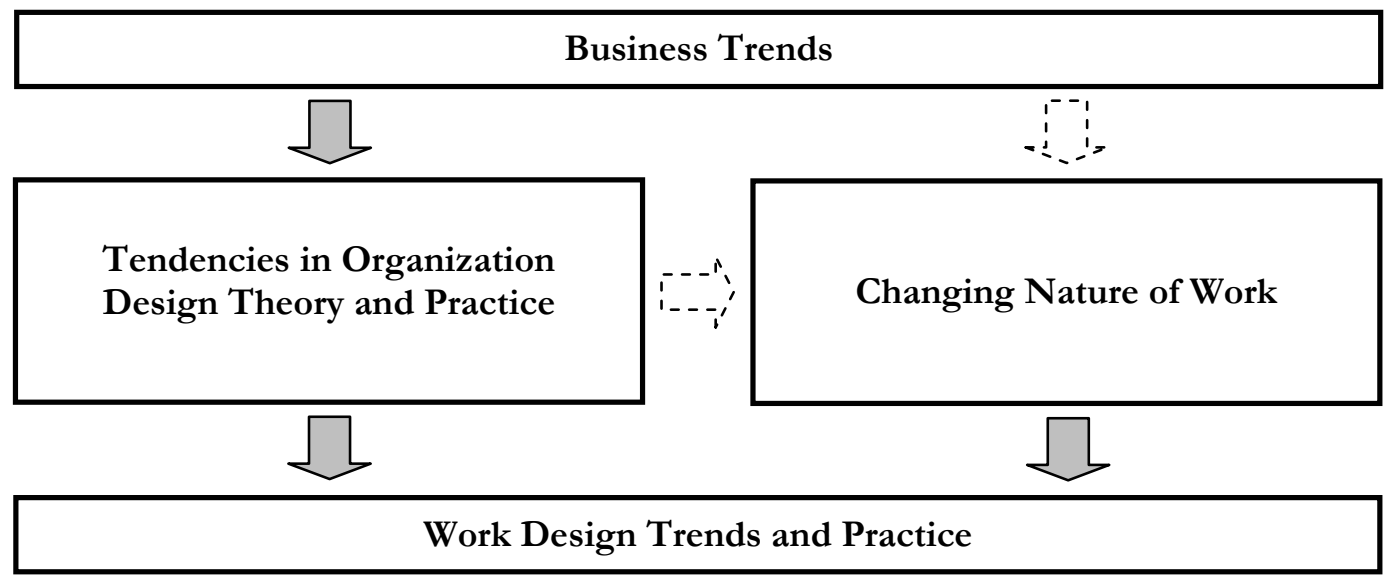

Interweaving of different trends and tendencies is evident (Figure 1) and logical because only their common understanding can explain complex reality of organizational practice. By reason of nature of trends and tendencies mentioned, one can say that opportunities of $21^{\text {st }}$ century can be found inside firms, in a way in which individual firms are organized. Exactly as Bryan and Joyce (2007) stated, if a firm has efficient internal organization, it can better seize opportunities for making profit offered in its environment. Correspondingly, it is extremely important to demonstrate interaction between tendencies and practice of organization design and trends and practice of work design in order to enable managers to make important business decisions aiming at optimizing organizational system, and not downgrading the importance of upcoming business trends.

Table 1: Overview of potentially strong influences of organization design tendencies on work design practice

\begin{tabular}{|c|c|c|c|c|c|c|c|c|}
\hline Organization Design & 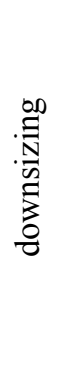 & 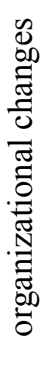 & 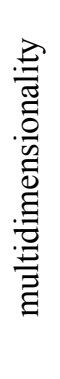 & 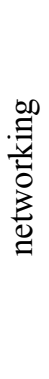 & 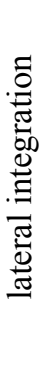 & 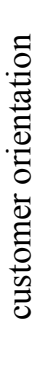 & 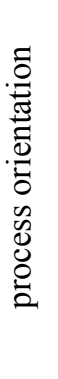 & 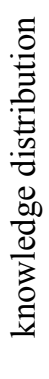 \\
\hline systemic character and higher complexity of work & $\checkmark$ & & $\checkmark$ & & $\checkmark$ & & & $\checkmark$ \\
\hline lack of clear job boundaries & $\checkmark$ & $\checkmark$ & $\checkmark$ & & $\checkmark$ & $\checkmark$ & $\checkmark$ & \\
\hline variability of work design & & $\checkmark$ & $\checkmark$ & & $\checkmark$ & & $\checkmark$ & $\checkmark$ \\
\hline stronger focus on work and competencies & & & $\checkmark$ & $\checkmark$ & & & $\checkmark$ & $\checkmark$ \\
\hline higher work interdependence & $\checkmark$ & $\checkmark$ & $\checkmark$ & $\checkmark$ & $\checkmark$ & $\checkmark$ & $\checkmark$ & \\
\hline emergence of group-based forms of work design & & $\checkmark$ & $\checkmark$ & & $\checkmark$ & $\checkmark$ & $\checkmark$ & \\
\hline wider use of various knowledge, skills and competencies & $\checkmark$ & $\checkmark$ & $\checkmark$ & & & $\checkmark$ & $\checkmark$ & $\checkmark$ \\
\hline optimal utilization of human potential & $\checkmark$ & $\checkmark$ & $\checkmark$ & & & & & $\checkmark$ \\
\hline job crafting & & & & & & & & $\checkmark$ \\
\hline
\end{tabular}

There are numerous cause-and-effect relationships present between tendencies of organization design and trends in work design, therefore, it is important to identify and stress only the most significant ones. In so doing, it is very difficult to separately analyze these impacts because all tendencies and trends act 
simultaneously. However, while in the previous table all potentially important impacts are exhibited, theoretical discussion should highlight the few most important cause-and-effect relationships.

PROPOSITON 1. Downsizing strategies make the work of employees more complex and systemic in nature.

PROPOSITION 2. Frequency, scope and speed of organizational changes lead to more variable work design for each particular individual.

PROPOSITION 3. Multidimensionality strongly influences the necessary level of work interdependence and results in more complex work design.

PROPOSITION 4. Networking and outsourcing strategy provide a stronger focus on work and competencies.

PROPOSITION 5. Lateral coordination boosts the emergence of group-based forms of work design and raises complexity of work.

PROPOSITION 6. C Customer orientation requests higher work interdependence.

PROPOSITION 7. Process orientation leads towards higher work interdependence and wider use of various knowledge, skills and competencies of employees.

PROPOSITION 8. Knowledge distribution causes higher complexity of work and stronger focus on competencies resulting in optimal utilization of human capital.

Flatter and more flexible organization structures, dynamic business processes, as well as changes in other organization design elements also require continuous changes in the practice of work design. To be more specific, organization design presents the main contextual element which can either limit or encourage processes of work design. Of course, all the changes are conditioned by the highest level and business trends which, in some cases directly, and others indirectly, impact the change of work nature inside an organization. In other words, nowadays in a business environment it is necessary to stress the presence of the systemic, i.e. multilevel features and interdependencies. Only by accepting and gaining better understanding of crucial interdependencies, it is possible to seize the opportunities and remove the threats of future organizing solutions.

\section{Conclusion}

In the organizational science the paradigm is developing that will bridge the macro-micro gap both in theory and in empirical research. There are positive changes happening in organizational research where a stronger focus is put on organizations as systems, while the systems theory of organizations and multilevel approach to organizations are more frequently used. A multi-level understanding of organizational reality will create preconditions for further improvement of organizational theory and practice by encouraging integration of the field. Starting from precisely decomposing the system on different subelements, but at the same time accepting its context, it offers potentially useful cognitions of interconnectivity and cause-andeffect relationships between different aspects.

In order to design organizations that will be able to confront successfully with upcoming competition and increasing changes in consumer expectations, it is necessary to look for systemic and cause-and-effect relationships between emerging practice at various levels of analysis - industry, organization, and work. Namely, job is not being done in vacuum but in organizations that make a part of a market or of a global economy in whole. The most successful organizations today are the ones capable of aligning flexible 
organizational solution with flexible forms of work design (Gyan-Baggour, 1999). Therefore, organization design does not only form, but also simultaneously limits possible choice, i.e. forms of work design.

In order to identify basic links and guidelines, in the paper current trends in doing business are presented, jointly with consequential tendencies at the organizational and work level. Furthermore, it is possible to assume that certain contextual factors can have a direct and stronger, and others indirect and weaker, impact on work design. Equally, certain trends in work design can be more limited by broader organizational context, while others can be under their minimal impact. Very important issue is a problem of alignment. Although the problem comes out from their different dynamics and change tendencies, organization design and work design should be and need to be analyzed as naturally complementary concepts.

Additionally to the problem of alignment, inability to precisely determine cause-and-effect relationships between various variables should be also emphasized as a research shortcoming. Although systems perspective conceptually strive for presenting realistic picture of the world with all the necessary interdependencies, thorough insights about the nature of particular relationships is almost impossible without ceteris paribus assumption.

Furthermore, cross-level and multi-level relationships can be, and usually they are, reciprocal in nature. In the paper, only top-down approach has been applied, leaving a plenty of space for future research activities aimed at investigating micro-macro influences. In both directions, additional empirical investigations should be conducted in order to gain better understanding of various bivariate and multivariate relationships. Such reciprocal influence between organizational behavior and work design from one side, and organizational theory and design from the other, is in compliance with main characteristics of systems theory of organizations, as well as supported by the emerging multi-level approach.

Contingency theory of organizations also supports such way of thinking and requires more theoretical and empirical research regarding alignment between various elements of organization design and work design, under the umbrella of business trends in general. As accomplishing alignment between macro- and microorganizational aspects presents one of the crucial and still insufficiently clear cognitions in the field of organization science, it is necessary to encourage further research on the topic. Finally, achieving a better understanding and harmonization can result in significant improvement of work and organizational success. At the same time, one should have in mind that business trends, and especially tendencies of organization design at macro level define the "playing field", while each organizational unit, team and/or individual in the organization should learn how to be effective and to "play" successfully in fundamentally different situations. In spite of existing constraints, there is still enough space and possibilities for differentiating successful from unsuccessful business practice at micro level of work design.

\section{References}

1. Aldrich, H. E. (1979). Organizations and Environments. Englewood Cliffs: Prentice Hall.

2. Becker, J., Kugeler, M., Rosemann, M. (2003). Process Management: A Guide for the Design of Business Processes. Berlin: Springer.

3. Beer, M. (1980). Organizational Change and Development: A Systems View. Santa Monica: Goodyear Publishing.

4. Bosilj Vukšić, V., Hernaus, T., Kovačič, A. (2008). Upravljanje poslovnim procesima: organizacijski i informacijski pristup. [Business Process Management: Organizational and IT approach]. Zagreb: Školska knjiga.

5. Bridges, W. (1994). Jobshift. Reading: Addison-Wesley.

6. Bryan, L. L., Joyce, C. I. (2007). Mobilizing Minds: Creating Wealth from Talent in the 21st-Century Organization. New York: McGraw-Hill.

7. Burlton, R. T. (2001). Business Process Management: Profiting from Process. Indianapolis: SAMS. 
8. Cameron, K. S., Freeman, S. J., Mishra, A. K. (1993). Downsizing and Redesigning Organizations. In Huber, G., Glick, W. (Ed.), Organizational Change and Redesign: Ideas and Insights for Improving Performance (pp. 19-65). New York: Oxford University Press.

9. Carroll, G. R. (1984). Organizational Ecology. Annual Review of Sociology, 10(1), 71-93.

10. Cohen, S. G., Mankin, D. (1998). The Changing Nature of Work: Managing the Impact of Information Technology. In Mohrman, S. A., Galbraith, J. R., Lawler III, E. E. et al. (Ed.), Tomorrow's Organization (pp. 154-178). San Francisco: Jossey-Bass.

11. Crosetto, G., Macazaga, J. (2005). The Process-Based Organization - A Natural Organization Strategy. Amherst: HRD Press.

12. Darwin, C. (1859). On the Origin of Species by Means of Natural Selection, or the Preservation of Favoured Races in the Struggle for Life. London: John Murray.

13. Davenport, T. H., Harris, J. G. (2007). Competing on Analytics: The New Science of Winning. Boston: Harvard Business School Press.

14. Davenport, T. H., Harris, J. G., Morison, R. (2010). Analytics at Work: Smarter Decisions, Better Results. Boston: Harvard Business School Press.

15. Despres, C., Chauvel, D. (2000). Knowledge Horizons: The Present and the Promise of Knowledge Management. London: Butterworth-Heinemann.

16. Duening, T. N., Click, R. L. (2005). Essentials of Business Process Outsourcing. New Jersey: John Wiley \& Sons.

17. Edwards, J. R., Scully, J. A., Brtek, M. D. (2000). The Nature and Outcomes of Work: A Replication and Extension of Interdisciplinary Work-Design Research. Journal of Applied Psychology, 85(6), 860868.

18. Finegold, D., Lawler III, E. E., Ledford Jr., G. E. (1998). Organizing for Competencies and Capabilities: Bridging from Strategy to Effectiveness. In Mohrman, S. A., Galbraith, J. R., Lawler III, E. E. et al. (Ed.), Tomorrow's Organization (pp. 133-153). San Francisco: Jossey-Bass.

19. Galbraith, J. R. (1994). Competing With Flexible Lateral Organizations. Reading: Addison-Wesley.

20. Galbraith, J. R. (2002). Designing Organizations: An Executive guide to strategy, structure, and process. San Francisco: Jossey-Bass.

21. Galbraith, J. R., Downey, D., Kates, A. (2002). Designing Dynamic Organizations. New York: AMACOM.

22. Galbraith, J. R., Lawler III, E. E. et al. (1993). Organizing for the Future. San Francisco: Jossey-Bass.

23. Gardner, R. A. (2004). The Process-focused Organization. Milwaukee: ASQ Quality Press.

24. Goold, M., Campbell, A. (2002). Designing Effective Organizations - How to Create Structured Networks. San Francisco: Jossey-Bass.

25. Grant, R. M. (2009). Contemporary Strategy Analysis. New York: John Wiley \& Sons.

26. Griffin, R. W. (1982). Task Design: An Integrative Approach. Glenview: Scott, Foresman and Co.

27. Guillén, M. F. (2008). Globalization and Organization Studies. In Barry. D., Hansen, H. (Ed.), The SAGE Handbook of New Approaches in Management and Organization (pp. 182-183). London: Sage Publications.

28. Gyan-Baggour, G. (1999). The Effects of Employee Participation and Work Design on Firm Performance: A Managerial Perspective. Management Research News, 22(6), 1-12.

29. Hannan, M. T., Freeman, J. (1977). The Population Ecology of Organizations. American Journal of Sociology, 82(5), 929-964.

30. Harmon, P. (2003). Business Process Change: A Manager's Guide to Improving, Redesigning, and Automating Processes. San Francisco: Morgan Kaufmann Publishers.

31. Hernaus, T. (2008). Process-Based Organization Design Model: Theoretical Review and Model Conceptualization. Third International Workshop on Organization Design, May 18-20, Aarhus.

32. Hesselbein, F., Goldsmith, M. (Ed.) (2009). The Organization of the Future 2: Visions, Strategies, and Insights on Managing in New Era. San Francisco: Jossey-Bass.

33. Howard, A. (Ed.) (1995). The Changing Nature of Work. San Francisco: Jossey-Bass.

34. Johansson, H. J., McHugh, P., Pendlebury, A., Wheeler III, W. A. (1993). Business Process Reengineering - Breakpoint Strategies for Market Dominance. New York: John Wiley \& Sons.

35. Katz, D., Kahn, R. L. (1966). The Social Psychology of Organizations. New York: John Wiley \& Sons. 
36. Kersley, B., Alpin, C., Forth, J., Bryson, A., Bewley, G. D., Oyenbridge, S. (2006). Inside the Workplace: Findings from the 2004 Workplace Employment Relations Survey. London: Routledge.

37. Klein, K. J., Kozlowski, S. W. J. (Ed.) (2000). Multilevel Theory, Research, and Methods in Organizations. San Francisco: Jossey-Bass.

38. Lawler III, E. E. (1996). From the Ground Up-Six Principles for Building the New Logic Corporation. San Francisco: Jossey-Bass.

39. Lawler III, E. E., Finegold, D. (2000). Individualizing the Organization: Past, Present, and Future. Organizational Dynamics, 29(1), 1-15.

40. Lawler III, E. E., Worley, C. G. (2006). Built to Change: How to Achieve Sustained Organizational Effectiveness. San Francisco: Jossey-Bass.

41. Liska, A. E. (1990). The Significance of Aggregate Dependent Variables and Contextual Independent Variables for Linking Macro and Micro Theories. Social Psychology Quarterly, 53(4), 292-301.

42. Lowman, R. L. (Ed.). Handbook of Organizational Consulting Psychology. San Francisco: JosseyBass.

43. Miles, R. E., Miles, G., Snow, C. C. (2006). Collaborative Entrepreneurship: A Business Model for Continuous Innovation. Organizational Dynamics, 35(1), 1-11.

44. Mintzberg, H. (1979). The Structuring of Organizations: A Synthesis of the Research. Englewood Cliffs: Prentice Hall.

45. Mohrman, S. A. (2002). The Organizational Level of Analysis: Consulting to the Implementation of New Organizational Designs. In Lowman, R. L. (Ed.), Handbook of Organizational Consulting Psychology (pp. 54-75). San Francisco: Jossey-Bass.

46. Mohrman, S. A. (2003). Designing Work for Knowledge-Based Competition. In Jackson, S. E., Hitt, M. A., Denisi, A. S. (Ed.). Managing Knowledge for Sustained Competitive Advantage (pp. 94-123). San Francisco: Jossey-Bass.

47. Mohrman, S. A. (2006). Strategic Organization Design Workshop. Los Angeles: Center for Effective Organizations, University of Southern California.

48. Mohrman, S. A., Cohen, S. G., Mohrman Jr., A. M. (1995). Designing Team-Based Organizations New Forms for Knowledge Work. San Francisco: Jossey-Bass.

49. Moorhead, G. (1981). Organizational Analysis: An Integration of the Macro and Micro Approaches. Journal of Management Studies, 18(2), 191-218.

50. Mossholder, K. W., Bedeian, A. G. (1983). Cross-Level Inference and Organizational Research: Perspectives on Interpretation and Application. Academy of Management Review, 8(4), 547-558.

51. Mozenter J. (1999). Emerging Trends in Organizational Development. Independent Study, Boston: Boston University.

52. Nadler, D. A., Gerstein, M. S., Shaw, R. B. et al. (1992). Organizational Architecture: Designs for Changing Organizations. San Francisco: Jossey-Bass.

53. Nonaka, I., Takeuchi, H. (1995). The Knowledge-Creating Company: How Japanese Companies Create the Dynamics of Innovation. New York: Oxford University Press.

54. Ohmae, K. (1995). The End of the Nation State: The Rise of Regional Economics. New York: Free Press.

55. Ostroff, F. (1999). The Horizontal Organization. New York: Oxford University Press.

56. Parker, B., Clegg, S. R. (2006). Globalization. In Clegg, S. R., Hardy, C., Lawrence T. B., Nord, W. R. (Ed.), The Sage Handbook of Organization Studies (pp. 651-674). London: Sage Publications.

57. Parker, S. K., Wall, T. D. (2001). Work Design: Learning from the Past and Mapping a New Terrain. In Anderson, N., Ones, D. S., Sinangil, H. K., Viswesvaran, C. (Ed.), Handbook of Industrial, Work and Organizational Psychology, Vol. 1 (pp. 90-110). London: Sage Publications.

58. Pasmore, W. A. (1994). Creating Strategic Change: Designing the Flexible, High-Performing Organization. New York: John Wiley \& Sons.

59. Roberts, K. H., Hulin, C. L., Rousseau, D. M. (1978). Developing and Interdisciplinary Science of Organizations. San Francisco: Jossey-Bass.

60. Roos, J. (1996). Managing Knowledge: Perspectives on Cooperation and Competition. Thousand Oaks: Sage Publications.

61. Rummler, G. A., Brache, A. P. (1995). Improving Performance: How to Manage the White Space on the Organization Chart. San Francisco: Jossey-Bass. 
62. Sanchez, J. I., Levine, E. L. (2001). The Analysis of Work in the $20^{\text {th }}$ and $21^{\text {st }}$ Centuries. In Anderson, N., Ones, D. S., Sinangil, H. K., Viswesvaran, C. (Ed.), Handbook of Industrial, Work and Organizational Psychology, Vol. 1 (pp. 71-89). London: Sage Publications.

63. Senge, P. (1990). The Fifth Discipline: The Art and Practice of the Learning Organization. New York: Doubleday.

64. Shafritz, J. M., Ott, J. S. (1987). Classics of Organization Theory. Chicago: The Dorsey Press.

65. Sikavica, P., Novak, M. (1999). Poslovna organizacija. [Business organization]. Zagreb: Informator.

66. Snow, C. C., Strauss, D. (2008). Blade.Org: A Collaborative Community of Firms. Third International Conference on Organization Design, May 18-20, Aarhus.

67. Swanson, R. A. (2007). Analysis for Improving Performance. San Francisco: Berrett-Koehler Publishers.

68. Tenner, A. R., DeToro, I. J. (2000). Process Redesign: The Implementation Guide for Managers. New Jersey: Prentice Hall.

69. Thompson, J. D. (1967). Organizations in Action. New York: McGraw-Hill.

70. Van de Ven, A. H., Ferry, D. L. (1980). Measuring and Assessing Organizations. New York: John Wiley \& Sons.

71. von Bertalanffy, L. (1951). General Systems Theory: A New Approach to Unity of Science. Human Biology, 23(4), pp. 303-361.

72. Walton, E., Nadler, D. A. (1994). Diagnosis for Organization Design. In Howard, A. et al. (Ed.), Diagnosis for Organizational Change: Methods and Models (pp. 85-105). New York: The Guilford Press.

73. Wrzesniewski, A., Dutton, J. E. (2001). Crafting a Job: Revisioning Employees as Active Crafters of Their Work. Academy of Management Review, 26(2), 179-201. 